\title{
KEAMANAN OBAT TRADISIONAL JAMU KUNYIT ASEM DI BEBERAPA PASAR TRADISIONAL KOTA MALANG
}

\author{
Nadia Firdausi ${ }^{1}$, Sandry Kesuma ${ }^{1}$, I Komang Suwita ${ }^{1}$, \\ 1) Program Studi ANAFARMA, Jurusan Gizi, Politeknik Kesehatan Kemenkes \\ Malang \\ e-mail: sandrykesuma1207@gmail.com
}

\begin{abstract}
ABSTRAK
Obat tradisional (jamu gendong) termasuk minuman tradisional yang masih dikonsumsi oleh masyarakat, sehingga harus diperhatikan keamanan obat tradisionalnya baik dari segi mikroba dan kimianya. Berdasarkan Peraturan BPOM RI No.12 Tahun 2014 tentang Persyaratan Obat Tradisional tidak boleh mengandung Eschericia coli dengan negatif/ml atau $<3 \mathrm{MPN} / \mathrm{ml}$ dan Peraturan BPOM No. 32 Tahun 2019 tentang Persyaratan Keamanan dan Mutu Obat Tradisional dengan batas penggunaan siklamat sebesar 1,250 g/L. Penelitian ini menggunakan metode MPN, pewarnaan gram dan gravimetri tujuannya untuk mengetahui cemaran Escherichia coli dan kandungan siklamat pada Jamu Kunyit Asem di beberapa Pasar Tradisional Kota Malang. Penelitian ini merupakan penelitian deskriptif desain observasional. Jumlah sampel yaitu 4 jamu kunyit asem dari Pasar Bareng, Pasar Besar, Pasar sukun dan Pasar Oro-Orodowo. Hasil pemeriksaan uji Escherichia coli yaitu 1 sampel positif mengandung Escherichia coli dengan nilai MPN 7,4 MPN/ml dan 1 sampel positif mengandung siklamat dengan kadar 4,0182 g/L yang tidak memenuhi persyaratan.
\end{abstract}

Kata kunci: Keamanan Obat Tradisional, Jamu Kunyit Asem, Escerichia coli, Siklamat

\section{ABSTRACT}

Traditional medicine (herbal medicine) including traditional drinks that are still consumed by the community, so it must be considered the safety of traditional medicine both in terms of microbes and their chemical aspects. Based from BPOM RI rules No. 122014 concerning requirements for traditional medicines may not contain Escherichia coli with negative/ml or $<3 M P N / m l$ and BPOM RI rules No. 322019 concerning safety and quality requirements of traditional medicines with a cyclamate use limit of $1,250 \mathrm{~g} g / \mathrm{L}$. The research uses the MPN method, gram staining and gravimetric aim to determine Escherichia coli contamination and cyclamate content in tamarind turmeric herbs in several traditional markets in Malang. The research is a descriptive research with observational design. The number of samples are 4 tamarind turmeric herbs from Bareng market, Besar market, Sukun market and Oro-orodowo market. The result of Escherichia coli test showed that 1 positive sample contained Escherichia coli with an MPN value of 7,4 MPN/ml and 1 positive sample contained cyclamate with levels of 4,0182 $\mathrm{g} / \mathrm{L}$ that didn't meet the requirements

Keywords: Safety of Traditional Medicine, Tamarind Turmeric Herbal, Escherichia coli, Cyclamate 
MEDFARM: Jurnal Farmasi dan Kesehatan, Vol.10, No.1, 2021, Hal. 11-17

e-ISSN : 2715-9957

p-ISSN: 2354-8487

\section{PENDAHULUAN}

Obat tradisional adalah bahan atau ramuan bahan yang berupa bahan tumbuhan, bahan hewan, bahan mineral, sediaan sarian (galenik) atau campuran dari bahan tersebut yang secara turun temurun telah digunakan untuk pengobatan, dan dapat diterapkan sesuai dengan norma yang berlaku di masyarakat (BPOM RI, 2014). Kata jamu telah terbiasa didengar oleh masyarakat Indonesia. Minum jamu dianggap oleh masyarakat bangsa Indonesia sebagai obat tradisional. Jamu biasanya terdiri dari tumbuh-tumbuhan dan juga dari bagian tubuh hewan. Sebagian masyarakat menyebutnya dengan pengobatan alternatif (Litbang Depkes, 2015).

Jamu gendong termasuk minuman tradisional yang masih dikonsumsi oleh masyarakat. Ada berbagai macam jenis jamu, salah satunya adalah jamu kunyit asem. Ditinjau dari segi mikrobiologinya dapat dilihat dari proses pembuatan yang masih sederhana serta kurangnya perhatian terhadap kebersihan menjadi salah satu penyebab jamu kunyit asem ini sering tercemar oleh mikroorganisme (Amellia, 2019). Sedangkan apabila ditinjau dari segi kimianya pemanis buatan sering ditambahkan ke dalam makanan dan minuman sebagai pengganti gula murni karena mempunyai beberapa kelebihan dibandingkan dengan pemanis alami, selain rasanya lebih manis dan harganya lebih murah, pemanis buatan juga dapat membantu mempertajam penerimaan terhadap rasa manis (Suratmono, 2009).

Berdasarkan Peraturan BPOM RI No.12 Tahun 2014 menyatakan bahwa salah satu persyaratan obat tradisional tidak boleh mengandung mikroba pathogen dengan negatif/ml untuk bakteri Escherichia coli dan pada Peraturan BPOM No. 32 Tahun 2019 tentang Persyaratan Keamanan dan Mutu Obat Tradisional menyatakan bahwa penggunaan bahan tambahan pangan berupa pemanis buatan pada jamu kunyit asem seperti halnya pemanis buatan siklamat masih dizinkan namun terdapat batas konsumsi siklamat pada obat tradisional yaitu 1,250 g/L.

Namun pada kenyataannya masih banyak ditemukan jamu tradisional yang mengandung bakteri Escherichia coli melebihi batas ketentuan. Berdasarkan hasil penelitian yang dilakukan Syahfitri (2016) di Kecamatan Medan Selayang didapatkan hasil sebanyak 50\% sampel jamu kunyit asem positif mengandung 
MEDFARM: Jurnal Farmasi dan Kesehatan, Vol.10, No.1, 2021, Hal. 11-17

e-ISSN : 2715-9957

p-ISSN: $2354-8487$

bakteri Escherichia coli dengan jumlah angka MPN Escherichia coli tidak memenuhi syarat dan juga hasil penelitian Lestari (2011) di Kota Semarang menyatakan bahwa dalam jamu gendong yang dijual di pasar Gubug telah menambahkan pemanis buatan yang berupa siklamat pada sebagian jamu yang mereka jual. Dengan kadar melebihi ambang batas yang telah ditetapkan yaitu pada sampel kunir asam A $(9,82 \mathrm{~g} / \mathrm{L})$, Sampel kunir asam B $(1,84 \mathrm{~g} / \mathrm{L})$, dan sampel kunir asam C (3,99 g/L).

Penelitian ini bertujuan untuk mengetahui cemaran bakteri Escherichia coli dan kandungan bahan tambahan pemanis siklamat pada Jamu Kunyit Asem yang diperdagangkan di beberapa Pasar Tradisional Kota Malang.

\section{METODOLOGI PENELITIAN}

Jenis penelitian yang digunakan adalah penelitian deskriptif dengan desain penelitian secara observasional, yaitu menggambarkan tentang keamanan obat tradisional mengenai kandungan Escherichia coli dan kandungan Siklamat pada jamu kunyit asem yang dijual di beberapa Pasar Tradisional Kota Malang. Hasil penelitian yang didapat, kemudian diolah dan disajikan dalam bentuk tabel selanjutnya dianalisis secara deskriptif. Metode penelitian yang digunakan yaitu Most Probable Number (MPN), pewarnaan gram dan gravimetri.

\section{HASIL DAN PEMBAHASAN}

Pada penelitian ini jumlah sampel jamu kunyit asem yang digunakan yaitu sebanyak 4 sampel yang diambil dari empat pedagang pasar yang berbeda dan dilabeli dengan kode 1818 (Pasar Bareng), 1819 (Pasar Oro-oro Dowo), 1820 (Pasar Besar), dan 1821 (Pasar Sukun). Pengambilan sampel dilakukan pada hari Senin, 17 Februari 2020, pukul 08.00 WIB. Kemudian sampel jamu dibawa kelaboratorium menggunakan coolbox.

Tabel 1. Hasil Uji Kandungan Escherichia coli pada jamu kunyit asem

\begin{tabular}{ccccc}
\hline No. & Kode Sampel & Hasil E.Coli & Nilai MPN & Keterangan \\
\hline 1. & 1818 & Negatif & $<3,0$ & MS \\
2. & 1819 & Negatif & $<3,0$ & MS \\
3. & 1820 & Negatif & $<3,0$ & MS \\
4. & 1821 & Positif & 7,4 & TMS \\
\hline
\end{tabular}

Keterangan : MS (Memenuhi Syarat)

TMS (Tidak Memenuhi Syarat) 
MEDFARM: Jurnal Farmasi dan Kesehatan, Vol.10, No.1, 2021, Hal. 11-17

e-ISSN : 2715-9957

p-ISSN: 2354-8487

Berdasarkan Tabel 1 didapatkan data dari 4 sampel jamu kunyit asem yang diperiksa, ditemukan 1 sampel dengan kode sampel 1821 yang diambil dari Pasar Sukun positif mengandung bakteri Escherichia coli dengan nilai MPN sebesar 7,4 MPN/ml dimana jumlah tersebut tidak memenuhi syarat kesehatan menurut Peraturan BPOM RI No.12 Tahun 2014 tentang persyaratan obat tradisional tidak boleh mengandung mikroba pathogen dengan negatif/ml atau 0 yang di dalam angka MPN dinyatakan $<3 \mathrm{MPN} / \mathrm{ml}$ untuk Bakteri Eschericia coli. Pada penelitian ini sampel dengan hasil positif menunjukkan gambaran mikroskop berbentuk basil pendek dan berwarna merah yang berarti gram negatif dengan demikian sampel 1821 positif mengandung Escherichia coli.

Masih ditemukannya cemaran bakteri Escherichia Coli pada sampel jamu kunyit asem hingga saat ini kemungkinan terjadi karena kontaminasi bakteri Escherichia coli dari penggunaan air yang masih belum masak sempurna ataupun dari peralatan masak dan botol wadah yang digunakan dimungkinkan beresiko menjadi tempat perkembangbiakan bakteri tersebut atau bisa juga dari higiene sanitasi yang masih kurang baik. Ditambah lagi, semua pedagang menjajakan dagangannya di pinggir jalan yang dapat tercemar oleh timbal atau asap kendaraan. Kualitas air yang digunakan merupakan salah satu bentuk penularan mikroorganisme penyebab timbulnya suatu penyakit. Hasil penelitian ini sejalan dengan penelitian Syahfitri (2016) di Kecamatan Medan Selayang didapatkan hasil sebanyak 50\% sampel jamu kunyit asem positif mengandung bakteri Escherichia coli dengan jumlah angka MPN Escherichia coli tidak memenuhi syarat.

Jumlah Escherichia coli dalam jamu kunyit asem yang melebihi standar tersebut dapat berisiko tinggi terhadap kesehatan konsumen. Bila daya tahan tubuh mereka tidak bagus, maka akan menyebabkan penyakit. Keberadaan Escherichia coli dalam air atau makanan dianggap memiliki korelasi tinggi dengan ditemukannya bibit penyakit (patogen) pada pangan. Escherichia coli yang pada keadaan tertentu dapat mengalahkan mekanisme pertahanan tubuh sehingga selanjutnya Escherichia coli dapat menyebabkan diare ataupun penyakit lainnya (Rahayu, 2007). 
MEDFARM: Jurnal Farmasi dan Kesehatan, Vol.10, No.1, 2021, Hal. 11-17

e-ISSN : 2715-9957

p-ISSN: 2354-8487

Tabel 2. Hasil uji kualitatif Siklamat pada jamu kunyit asem

\begin{tabular}{ccc}
\hline No. & Kode Sampel & Hasil \\
\hline 1. & 1818 & Negatif \\
2. & 1819 & Negatif \\
3. & 1820 & Positif \\
4. & 1821 & Negatif \\
\hline
\end{tabular}

Pada tabel 2 dapat dilihat bahwa salah satu sampel jamu dengan kode 1820 dari menunjukkan hasil yang positif mengandung pemanis siklamat. Hasil pengujian lebih lanjut pada sampel 1820 diperoleh kadar asam siklamat dan natrium siklamat adalah 4,0182 g/L dan 4,5105 g/L, dimana kadar tersebut melebihi ambang batas yang telah ditentukan pada Peraturan BPOM No. 32 Tahun 2019 tentang Persyaratan Keamanan dan Mutu Obat Tradisional dengan batas penggunaan pemanis buatan siklamat pada obat tradisional sebesar 1,250 g/L.

Banyak faktor yang menyebabkan digunakannya pemanis buatan seperti siklamat. Pemanis buatan sering ditambahkan ke dalam makanan dan minuman sebagai pengganti gula murni karena mempunyai beberapa kelebihan dibandingkan dengan pemanis alami, selain rasanya lebih manis dan harganya lebih murah, pemanis buatan juga dapat membantu mempertajam penerimaan terhadap rasa manis. Penyebab-penyebab ini dapat ditinjau dari aspek sosial, ekonomi termasuk infrastuktur yang masih lemah. Beberapa penyebab ini berwujud dalam bentuk masih rendahnya penerapan cara produksi yang baik, rendahnya permodalan penjaja, serta masih rendahnya pengetahuan penjaja dan konsumen tentang keamanan obat tradisional. Sekalipun penggunaannya diizinkan, pemanis buatan dan juga bahan kimia lain sesuai dengan peraturan penggunaannya harus dibatasi (Suratmono, 2009). Hasil penelitian ini didukung dengan hasil penelitian Lestari (2011) di Kota Semarang bahwa dalam jamu gendong yang dijual di pasar Gubug telah menambahkan pemanis buatan yang berupa siklamat pada sebagian jamu yang mereka jual. Dengan kadar melebihi ambang batas yang telah ditetapkan yaitu pada sampel kunir asam A $(9,82 \mathrm{~g} / \mathrm{L})$, Sampel kunir asam B (1,84 g/L), dan sampel kunir asam C (3,99 g/L). Demikian juga pada hasil penelitian Andi Akbar dkk (2015) di Kota Makassar menyatakan bahwa Sampel jamu kunyit asem terbukti mengandung pemanis siklamat. 
MEDFARM: Jurnal Farmasi dan Kesehatan, Vol.10, No.1, 2021, Hal. 11-17

e-ISSN : 2715-9957

p-ISSN: 2354-8487

Dengan kadar sebesar 7,0588 g/L menandakan kadar siklamat melebihi ambang batas.

\section{SIMPULAN}

Hasil uji kandungan Escherichia coli pada keempat sampel jamu kunyit asem diperoleh 1 sampel mengandung Escherichia coli dengan nilai MPN sebesar 7,4 MPN/ml yang tidak memenuhi persyaratan BPOM.

Hasil uji kandungan Siklamat pada keempat sampel jamu kunyit asem diperoleh 1 sampel positif mengandung pemanis buatan berupa siklamat dalam jamu kunyit asem yang dijual dengan kadar 4,0182 g/L yang tidak memenuhi persyaratan BPOM.

\section{DAFTAR PUSTAKA}

Andi Akbar, ST Fajriani, Diana Sanda S. 2015. Identifikasi Kandungan Dan Kadar Pemanis Buatan Siklamat Dalam Jamu Gendong. Jurusan Kimia, Fakultas Matematika Dan Ilmu Pengetahuan Alam. Universitas Hasanuddin. Makassar

Amelia Valentina R S. 2019. Pemeriksaan Mpn (Most Probable Number) Coliform Dan Identifikasi Escherichia Coli Pada Jamu Gendong Beras Kencur. Jurusan Analis Kesehatan Poltekkes Kemenkes Semarang. Semarang.

BPOM RI. (2014). Persyaratan Mutu Obat Tradisional. Jakarta: Badan Pengawas Obat dan Makanan.

BPOM RI. 2019. Persyaratan Keamanan dan Mutu Obat Tradisional. Jakarta: Badan Pengawas Obat dan Makanan.

Jamu \& Kesehatan Edisi II. [online].Jakarta: Badan Penelitian dan Pengembangan Kesehatan. Dapat diakses di terbitan.litbang.depkes.go.id/penerbit/index.php/lpb/catalog/downloa d/372-1

Lestari, Dewi. 2011. Analisis Adanya Kandungan Pemanis Buatan (Sakarin Dan Siklamat) Pada Jamu Gendong Di Pasar Gubug Grobogan. Skripsi. Ilmu Pendidikan Kimia. Institut Agama Islam Negeri Walisongo. Semarang.

Rahayu, S., dan Djafar, TF. 2007. Cemaran Mikroba Pada Produk Pertanian, Penyakit yang Ditimbulkan dan Pencegahannya. Jurnal Litbang Pertanian, 26(2):67-75 
MEDFARM: Jurnal Farmasi dan Kesehatan, Vol.10, No.1, 2021, Hal. 11-17

e-ISSN : 2715-9957

p-ISSN: 2354-8487

Suratmono, 2009. Penggunaan Data Hasil Pengujian Untuk Meningkatkan Pengaturan Keamanan Pangan: Studi Kasus Siklamat Pada Pangan Jajanan Anak Sekolah: Tesis Mahasiswa Institut Pertanian Bogor

Syafitri, Fajar Dewi. 2016. Higiene Sanitasi Pengolahan dan Pemeriksaan Kandungan Escherichia coli pada Jamu yang Dijual Dengan Menggunakan Gerobak di Kecamatan Medan Selayang Tahun 2016. Universitas Sumatera Utara. Medan. 